\title{
Az adó- és vámhatóság szervezeti kultúrája
}

\section{SUBA Lászlón}

\begin{abstract}
A tanulmány szerzője vázlatosan bemutatja az állami adó- és vámhatóság megalakulásának történetét, majd a Nemzeti Adó- és Vámhivatal (NAV) hierarchiájának felvázolásából kiindulva elemzi a hivatal szervezeti kultúráját. Emellett igyekszik képet adni a két jogelődszervezet integrációjából adódó sajátosságokról is, végül kitér a szervezet kommunikációjának néhány kérdésére is. A szerző célul tüzte ki egyrészt azt, hogy betekintést adjon egy nagyon sajátos, "rendvédelmi feladatokat ellátó" szervezet müködésébe, másrészt pedig - ezzel szoros összefüggésben - röviden dokumentálni kívánja a "civil" és fegyveres rendvédelmi szerv összeolvadásának történetét.
\end{abstract}

Kulcsszavak: adóhatóság, kommunikáció, Nemzeti Adó- és Vámhivatal, szervezeti kultúra, vámhatóság

\section{A Nemzeti Adó- és Vámhivatal szervezeti hierarchiája}

A Nemzeti Adó- és Vámhivatal - jogállását tekintve - „államigazgatási és fegyveres rendvédelmi feladatokat ellátó, a Kormány eredeti jogalkotói hatáskörében kiadott rendeletében kijelölt miniszter (a továbbiakban: kijelölt miniszter) által irányított, központi hivatalként müködő központi költségvetési szerv”. „A Nemzeti Adó- és Vámhivatal 2011. január 1-jével az Adó- és Pénzügyi Ellenőrzési Hivatal és a Vám- és Pénzügyőrség összeolvadásával jön létre, ezzel egyidejűleg az Adó- és Pénzügyi Ellenőrzési Hivatal és a Vám- és Pénzügyőrség megszűnik."3 Tekintettel arra, hogy nem előzmény nélküli, teljesen új szervezetről van szó, célszerű röviden bemutatni a jogelődök felépítését.

\section{Az Adó- és Pénzügyi Ellenôrzési Hivatal ${ }^{4}$}

Az Adó- és Pénzügyi Ellenőrzési Hivatal 1987. július 1-jével jött létre. Szervezete a jogelőd intézmények, a Pénzügyminisztérium Bevételi Főigazgatóság, a megyei adómegállapító hivatalok és az illetékhivatalok szakembereinek tudására és munkájára épült.

SUBA László, pénzügyőr alezredes, tanársegéd, NKE RTK, Vám-és Pénzügyőr Tanszék

László SUBA, Customs Officer Lieutenant Colonel, Instructor, National University of Public Service Faculty of Law Enforcement Department of Customs and Finance

https://orcid.org/0000-0001-6251-4654; suba.laszlo@nav.gov.hu

2010. évi CXXII. törvény a Nemzeti Adó- és Vámhivatalról (NAV tv.).

NAV tv. 87. § (1) bek.

Szabó (é. n.) 36-39. 
A háromszintü adószervezet tevékenysége kiterjedt valamennyi adóalanyra, az adók és adójellegű kötelezettségek nyilvántartására, beszedésére, a támogatások kiutalására, azok kezelésére, ellenőrzésére és a mulasztókkal szembeni kényszerintézkedések és azok jogkövetkezményeinek érvényesítésére.

1992. január 1-jén az addigi háromszintű szervezet kétszintűvé vált úgy, hogy az adófelügyelőségek a megyei (fővárosi) igazgatóságok szervezetébe integrálódtak. A tevékenységek egységesítése érdekében négy nagy szervezeti - adóügyi, ellenőrzési, végrehajtási és müködtetési - szakterületet hoztak létre, mind a Központi Hivatalon, mind pedig az igazgatóságokon belül. Az 1997-es esztendőben a szigorú és következetes adóhatósági fellépés mellett megjelent a szolgáltató hatóság képe. 1999-ben döntés született az APEH tevékenységének nyomozati jogkörrel történő bővítéséről: létrejött az APEH Bűnügyi Igazgatósága és annak területi nyomozóhivatalai.

A belsô szakmai képzés folyamatos biztosítása érdekében 2000-ben létrehozták az Oktatási Igazgatóságot, ahol szakmai ismeretek megszerzésére, folyamatos továbbképzésre és a készségek fejlesztésére egyaránt lehetőség volt.

2007-től a kormány a regionális szervezeti struktúra felállításáról és müködtetéséről rendelkezett, ${ }^{5}$ ekkor hét regionális és egy országos illetékességű igazgatóság jött létre, majd 2010-ben újból háromszintûvé vált az állami adóhatóság szervezete: megalakult a hét regionális főigazgatóságból és az azok alá tartozó 19 megyei igazgatóságból álló szervezet.

\section{A Vám- és Pénzügyőrség}

Az önálló magyar pénzügyőrség jóval nagyobb múltra tekinthet vissza. A magyar királyi pénzügyőrség létrehozása Lónyay Menyhért pénzügyminiszter nevéhez füződik, aki 1867. március 10-én kelt 1. számú körrendeletével hozta létre a testületet. ${ }^{6}$ A pénzügyőrség - jogállását tekintve - „a magyar államkincstár bevételeit biztosító, azaz a gazdasági rendvédelmünk feladatait kizárólagosan ellátó, katonailag szervezetten múködő szaktestület volt”. 7 Tekintettel arra, hogy jelen tanulmánynak nem célja a mélyreható testülettörténeti vizsgálódás, s mivel egyébként is a 2011-es összevonáskor létező Vám- és Pénzügyőrségről is elmondható, hogy feladata a gazdasági rend védelme volt, szervezeti struktúrája pedig a katonai hierarchián alapult, csupán a NAV létrehozásakor meglévő szerkezetről ejtek szót. 
A testület 2008-ban megvalósult szervezeti átalakítása eredményeként a szervezeti hierarchia csúcsán továbbra is a Vám- és Pénzügyőrség Országos Parancsnoksága volt, amely ellátta a középfokú szervek irányítását. A középfokú szervek közül elsőként említendők a 2000-ben uniós normáknak megfelelően az uniós régiókhoz területileg illeszkedve létrejött regionális parancsnokságok, vám- és jövedéki feladatok ellátására szakosodva. Felügyeletük alá tartoztak az alsófokú szervek. További speciális feladatokat ellátó középfokú szervek: a központi bűnüldözési, a központi ellenőrzési, a járőrszolgálati, a számlavezető parancsnokság, a vegyvizsgáló intézet, valamint a bűnügyi ellátó nyomozó hivatal, amelyek mindannyian hatósági jogkörrel rendelkező önálló középfokú szervekként múködtek. 2004 augusztusában kezdték meg múködésüket a regionális nyomozó hivatalok. Ezen szervek sorát a kiszolgáló funkciókat ellátó pénzügyi, oktatási, informatikai fejlesztési, valamint a szociális, kulturális és sporttevékenységet ellátó szervezeti egységek egészítették ki. Az alsófokú szervek: a vám- és pénzügyőri hivatalok, a regionális ellenőrzési központok, illetve a mélységi ellenőrzési csoportok. ${ }^{8}$

A Vám- és Pénzügyőrség az adópolitikáért felelős miniszter irányítása alatt álló fegyveres rendvédelmi, államigazgatási szerv volt, amely országos hatáskörrel rendelkező, önállóan működő és gazdálkodó központi költségvetési szervként múködött. ${ }^{9}$

\section{A Nemzeti Adó- és Vámhivatal szervezete}

A Nemzeti Adó- és Vámhivatal államigazgatási és fegyveres rendvédelmi feladatokat ellátó, központi hivatalként múködő központi költségvetési szerv. ${ }^{10}$ A Szervezeti és Múködési Szabályzat ${ }^{11}$ úgy rendelkezik, hogy „a NAV vezetőjének feladat- és hatáskörét a Pénzügyminisztérium (a továbbiakban: PM) Nemzeti Adó- és Vámhivatal vezetéséért felelős államtitkára (a továbbiakban: NAV vezetője) gyakorolja”. ${ }^{12}$ A szervezeti felépítést áttekinthetően szemlélteti az 1. ábra.

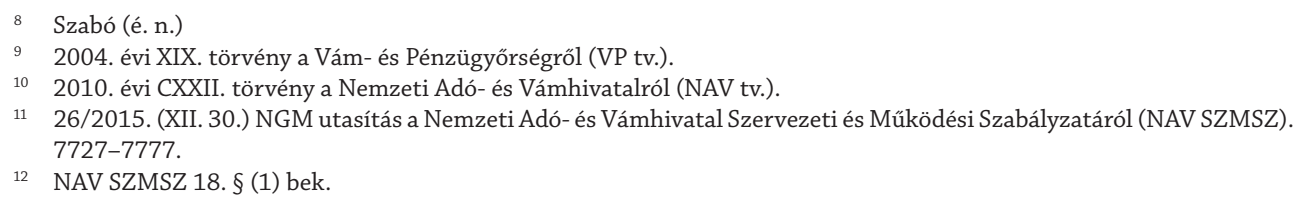




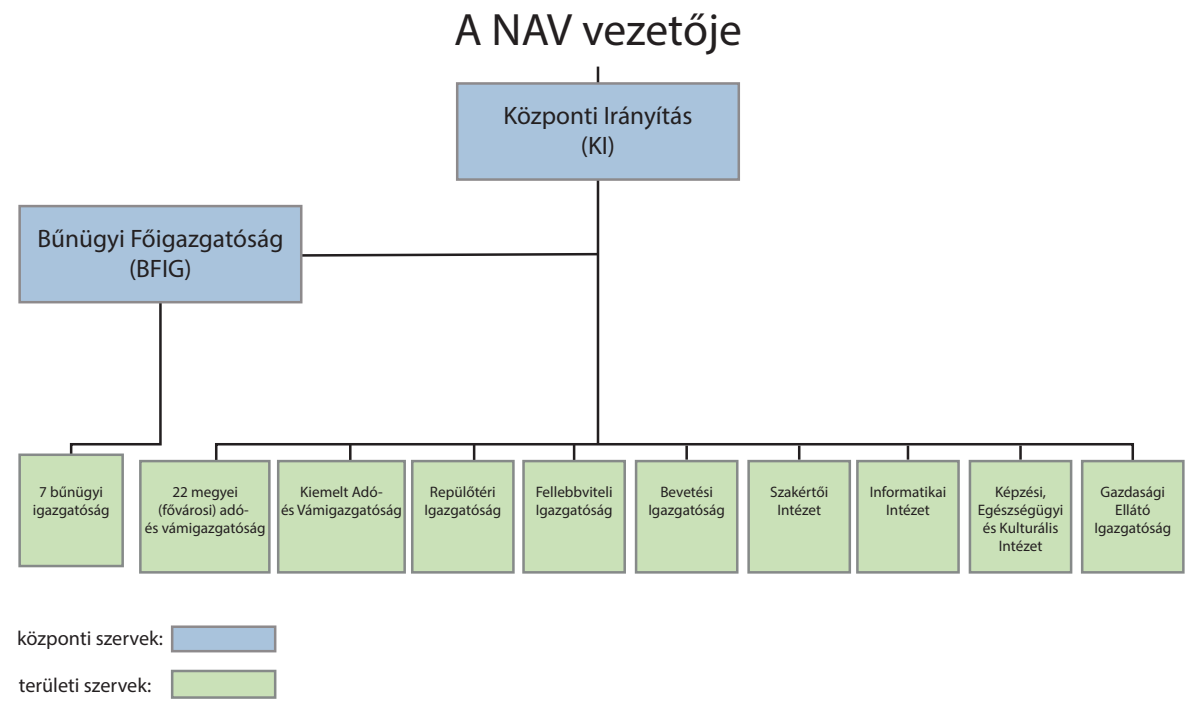

1. ábra: A NAV szervezeti felépitése. Forrás: NAV SZMSZ, 1. függelék

Amint az ábrából látható, a szervezet hierarchiája kétszintú. A felső szint magában foglalja a Központi Irányitást, valamint a Bünügyi Fóigazgatóságot. Közülük a Központi Irányítás mégis kiemelt szerepet tölt be, mert „a Bűnügyi Főigazgatóság és a területi szervek tevékenysége felett gyakorolja a jogszabályban biztosított irányítási és felügyeleti jogkörét, koordinálja múködésüket". ${ }^{13}$ A NAV vezetőjének (aki a Pénzügyminisztérium államtitkára) kiemelt szerepét mutatja, hogy közvetlenül vezeti a Központi Irányítást, szervezetirányítási jogkörét munkaszervezetén, a Központi Irányításon keresztül gyakorolja, továbbá képviseli a NAV-ot, illetve meghatározza a képviselet rendjét. ${ }^{14}$ A vezetésben az alábbi helyettesek múködnek közre: a NAV adószakmai ügyeiért felelős szakmai helyettes és a NAV bünügyi, vámszakmai és rendészeti feladatai ellátásáért felelős szakmai helyettes (mindketten a Pénzügyminisztérium helyettes államtitkárai). ${ }^{15}$ A szakföigazgató a feladatkörében eljárva támogatja a szakmai helyettes vagy a NAV vezetője munkáját. ${ }^{16} \mathrm{~A}$ Bünügyi Főigazgatóságot fốigazgató vezeti és képviseli, ${ }^{17}$ továbbá

\footnotetext{
NAV SZMSZ 9. §.

NAV SZMSZ 19. §.

NAV SZMSZ 20. §.

NAV SZMSZ 31. §.

NAV SZMSZ 28. §.
} 
a NAV gazdasági vezetőjének feladat- és hatáskörét a Központi Irányítás főigazgatója gyakorolja. $^{18}$

A NAV megalakulásakor az adóigazgatási és a vámigazgatási szervek még mind közép-, mind pedig alsó fokon elkülönülten múködtek. A mára kétszintűvé vált szervezeti hierarchia alsó szintjén már egységes adó- és vámhatósági szervezeti egységeket találunk. E szervezeti struktúra a Kiemelt Adó és Vám Főigazgatóság (KAVFIG) átszervezésével kezdődött: „a KAVFIG az első példa arra, hogy az adóellenőrzési, valamint a vám- és pénzügyi igazgatási feladatokat egy szerv keretében látják el; ez összefügg azzal a szakmai célkitűzéssel, hogy az adó- és vámigazgatási feladatokat az egységes szervezeten belül egyre inkább összehangoltan s így hatékonyabban lássák el”. ${ }^{19}$

\section{A Nemzeti Adó- és Vámhivatal szervezeti kultúrája}

Mindenekelőtt tisztázandó, hogy mit értünk szervezeti kultúra alatt, mert ez a fogalom korántsem tủnik olyan egyértelműen meghatározhatónak és feltérképezhetőnek, mint az előző fejezetben kifejtett szervezeti hierarchia. „A szervezeti kultúra nem más, mint a szervezet tagjai által elfogadott, közösen értelmezett elöfeltevések, értékek, meggyőződések, hiedelmek rendszere. Ezeket a szervezet tagjai érvényesnek fogadják el, követik s az új tagoknak is átadják, mint a problémák megoldásának követendő mintáit, és mint kívánatos gondolkodási és magatartásmódot." ${ }^{20}$ Lényegében ugyanezt a definíciót fogadja el kiindulópontként a Nemzeti Közszolgálati Egyetem közszolgálati közös moduljának tankönyve, ${ }^{21}$ illetve más releváns forrás is. ${ }^{22}$ Más megfogalmazás szerint a szervezeti kultúra „mindazon formális-normatív és informális hatásoknak, mechanizmusoknak, tényezőknek az együttese, amelyek a szervezet tagjainak munkahelyi magatartását, egymáshoz való viszonyát és mentalitását, gondolkodásmódját meghatározzák, illetve többé-kevésbé szerves egységbe foglalják. Mindezt egyszerübben úgy fogalmazhatjuk meg, hogy a szervezeti kultúra a szervezet tagjainak viselkedését és tudatvilágát vezérlő szabályozó rendszer". ${ }^{23}$

\section{Kultúramodellek - a NAV szervezeti kultúrája}

A szervezeti kultúra nem szervezettől, szervezettípustól függetlenül létező, egységes képződmény, hanem mint arra több kutató is rámutat, típusokba sorolható. Terjedelmi okból itt csupán Handy kultúratipológiájáról ejtek szót, és ez alapján vizsgálom a NAV kultúramodelljét.

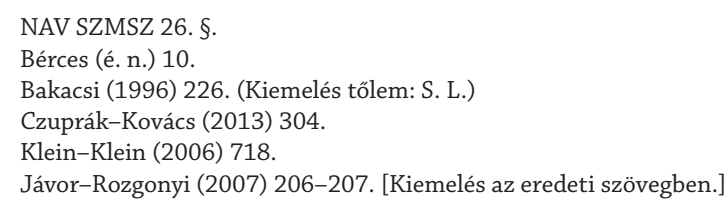


Handy szerint a különböző tevékenységeket végző szervezetek eltérő értékrendet fejlesztenek ki, s ez a kulturális különbözőség a szervezeten belül is megfigyelhető. A Handy által megkülönböztetett négy jellegzetes kultúra eltérései tehát a sajátos tevékenységfajtához kötődő sajátos értékrendből fakadnak. ${ }^{24}$

- A hatalomkultúra fő eleme egy központi szereplő, akiből minden irányba hatalom sugárzik. Kevés szabály létezik, a szervezet múködése sokkal inkább a központi szereplő kívánságainak teljesítésére irányul. A döntések nem logikai vagy ügyrendi kérdések, hanem az erőviszonyok alakulásának függvényei. Az ilyen típusú szervezet gyorsan képes reagálni a változásokra, ha a középponti személy képességei ezt lehetővé teszik. A minden irányba kisugárzó hatalom metaforája a pókháló. E kultúra jellemzi a kisebb, vállalkozó típusú szervezeteket. ${ }^{25}$

- A szerepkultúra voltaképpen bürokratikus kultúra. A logika és az észszerűség alapján múködik. Középpontja a szerep, a betöltött pozíció, munkakör. A hatalom mindig ehhez a szerephez, sosem az azt betöltő személyhez kötődik. E kultúra szimbóluma a görög oszlopcsarnok, amelynek tartóoszlopai a funkcionális szakterületek a maguk szakismeretével és hatáskörével. A tartóoszlopok és együttmúködésük kontrollja az ügyrendi szabályozók által biztosított. A tartóoszlopokat összefogó és lezáró timpanon a személyes koordinációt gyakorló szúk körü vezetés. A szerepkultúra változatlan környezetben múködik hatékonyan, ugyanakkor belül is stabilitás jellemzi. ${ }^{26}$

- A feladatkultúra projektirányultságú, metaforája a háló, leggyakrabban mátrixszervezetként jelenik meg. A feladatkultúra fő törekvése egy adott munka elvégzése, ehhez rendeli hozzá a szükséges erőforrásokat. A befolyás forrása elsősorban a szakértelem, kisebb mértékben a személyiség, a pozíciónak csupán másodlagos jelentősége van. Kifejezetten jó alkalmazkodóképesség jellemzi. Sebezhető pontja ugyanakkor a szervezet kontrollja, az erőforrások projektekhez való hozzárendelése. Az erőforrások szúkössége konfliktusok forrása lehet. ${ }^{27}$

- A személyiségkultúra jellemzően ügyvédi kamarák, partnerek által vezetett tanácsadó, auditáló cégek kultúrája. A középpontban a kiemelkedő szaktudású személyek állnak, akik szabad akaratukból döntenek úgy, hogy összefogva közös szervezetet alakítanak ki. Az ilyen típusú szervezet leginkább az egyének halmazaként értékelhető, a partnerek közös megegyezésén alapul, nem tűr vezetői hierarchiát. $^{28}$

A fent vázolt kultúramodellek közül a szerepkultúra nagy bürokratikus szervezetekre jellemző kultúratípus, ilyen például a hadsereg. ${ }^{29}$ Ugyanide sorolható a Nemzeti Adó-

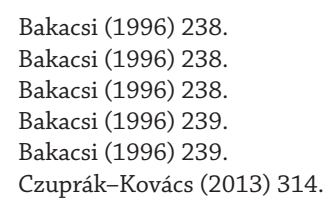


és Vámhivatal is, olyannyira, hogy a NAV vezetőjének a 2018-as évet értékelő előadásában is felfedezhető az a görög oszlopcsarnok, amely jól szemlélteti a NAV szervezeti felépítését (2. ábra).

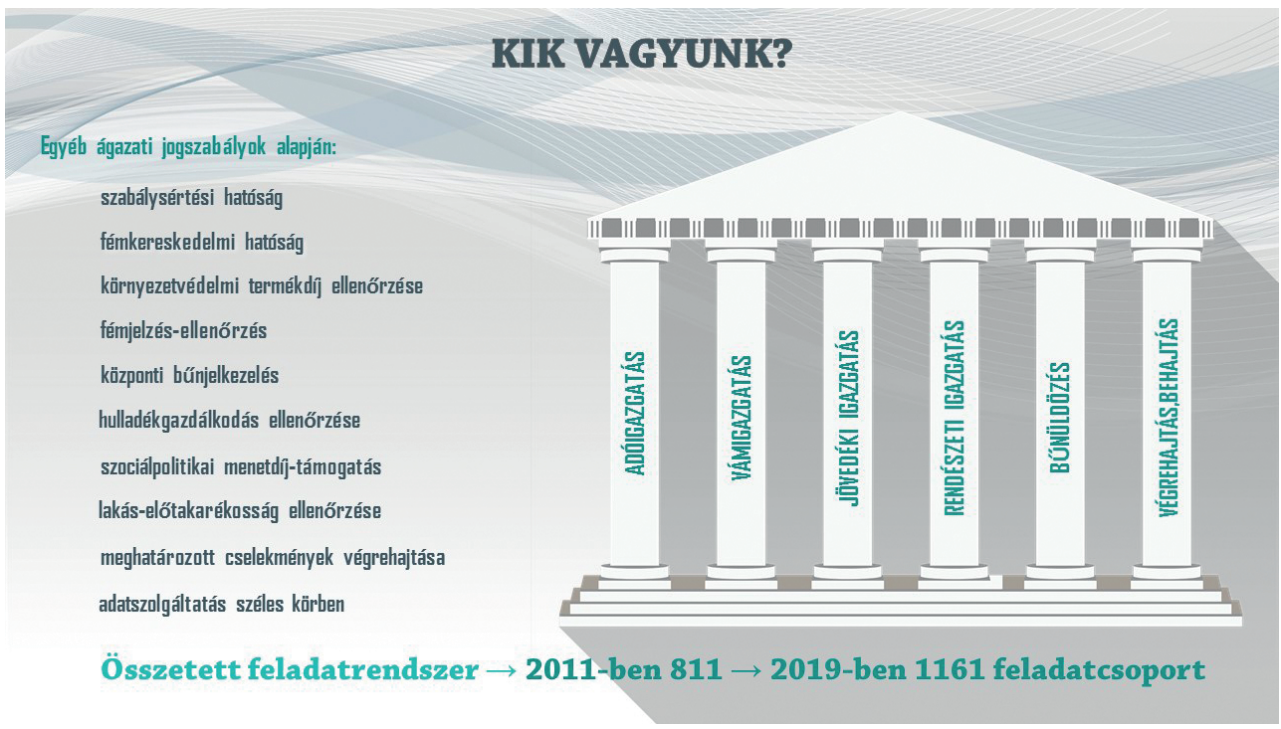

2. ábra: A NAV szervezetét bemutató görög oszlopcsarnok. Forrás: a NAV vezetőjének évértékelője, 2019. február 7. https://nav.gov.hu/nav/sajtoszoba/hirek/Evertekelo20190211.

html (2019. 10. 07.)

A szervezet a szerepeket szabályozó ügyrendek által működik, ezeknek jól körülhatárolható rendszerük van, összefoglaló elnevezésük: NAV-rendelkezések. ${ }^{30}$ Ezek sorában közjogi szervezetszabályozó eszközként utasítás, más irányító eszközként eljárási rend, szabályzat, parancs és körlevél, jogalkalmazást segítő eszközként pedig útmutató, tájékoztatás, módszertani segédlet és felhívás adható ki. E szabályozók mintegy „beprogramozzák" a szervezet tagjainak mindennapi tevékenységét. Hasonlóan e rendelkezésekhez, meglátásom szerint a napi, főként a rutinszerű tevékenységeket nagyon szúk mederbe tereli az (egyébként örvendetesen növekvő) elektronizált eljárások rendszere. Mind az adó-, mind pedig a vámeljárások során az ügyek jelentős része elektronikusan is intézhető, sőt, vannak olyan ügytípusok, amelyeket csak elektronikusan lehet intézni. Nagyon sok esetben - leginkább a vámigazgatási eljárások során - szükség van arra, hogy a NAV válaszüzenetet küldjön az ügyfélnek (például engedélyezze egy adott szállítmány kirakását): ezen üzenetek nagy része automatikus. A folyamatot megszakíthat-

$30 \quad$ NAV SZMSZ 3. §. 
ja ugyan a pénzügyőr, de joggal érezheti magát „a számítógép meghosszabbításának”. Önmegvalósításra tehát - Handy modelljellemzését alátámasztva - a szervezet nagy részében nincs lehetőség, csupán a szervezet felső rétegei nyújtanak erre módot.

\section{A követendö értékekröl}

A szervezeti kultúra egyik építőköve azon értékek együttese, amelyeket a szervezet tagjai értékként elfogadnak és követendőnek ítélnek. Robbins nyomán tizenegy ilyen értéket vázolhatunk fel. ${ }^{31}$

1. Munkakörrel vagy a szervezettel való azonosulás. A NAV esetében nem szabad szem elől téveszteni azt a tényt, hogy két különböző habitusú szervezet jogutódjáról van szó. Úgy vélem, a munkakörrel való azonosulás intenzitása az integráció következtében nem változott. Talán a pénzügyőrök vonatkozásában - az egyenruha-viselés, az alaki szabályok kötöttsége és az 1867-re visszavezethető testületi múlt okán - ez hangsúlyosabban valósul meg. A szervezettel való azonosulást pedig talán inkább szakággal („az oszlopcsarnok oszlopával”) való azonosulásként értelmezhetjük. ${ }^{32}$ Jól illusztrálja e kettősséget egy NAV-os munkatárs integrációt követő tapasztalata: „Igazán elgondolkodtató kép: Kibővített NAV-vezetői esemény, ahol nagy számban vannak jelen volt APEH-es és VPOP-s vezetők is. A felső vezetés, élén a NAV elnökével bevonul a terembe, a teremben tartózkodó rangidős pénzügyőr kiadja a parancsot: Elöljáró, fel, vigyázz! A pénzügyőrök természetesen azonnal tudják a teendőt, de mit is csinál ilyenkor egy civil? Hogy néz az ki, hogy ő ülve marad, miközben az egyenruhások mellette vigyázzban állnak? Természetesen ők is felállnak, bár valószínúleg lehetne némi alaki kifogást találni a mozdulataikban és a testtartásukban." 33 Ugyancsak a két szervezeti kultúra különbségének szemléltetésére ismét egy - talán a hajdani közszolgálati tisztviselők napjához kapcsolódó - saját tapasztalat: a központi ünnepség kezdete előtt rendszerint a Kuruc induló hangjaira a díszőrség ünnepélyesen bevonul a csapatzászlóval, a végén pedig ugyanígy távozik. A szervezők utasítása szerint ez alkalommal a csapatzászlót csendben behozták, a díszőrség parancsnoka csendben, szinte suttogva vezényelt. Később, az ünnepség után hallottam sommás véleményét: „Uraim, ez nem a zászló bevonulása volt, hanem a zászló besunnyogása."

2. Egyén- vagy csoportközpontúság. Bár a NAV tevékenysége rendkívül sokoldalú, valamennyi területen egyértelműen csoportokba szervezett munkáról beszélhetünk. Kollektív tevékenységet igényel bármilyen ellenőrzés (egyedül nem is végezhető!), a bűncselekmények nyomozása, de még egy rutinszerű igazgatá-

\footnotetext{
31 Bakacsi (1996) 226.

32 Még maga a NAV tv. is úgy fogalmaz, hogy: „12/A. § A NAV - mint állami adó- és vámhatóság - látja el a) az állami adóhatóság és b) a vámhatóság jogszabályban meghatározott feladatait.”

33 Belényesi (2014) 133.
} 
si cselekmény is több munkatárs együttes tevékenységét igényli, elsősorban a szervezeti és az egyéni integritás érdekében.

3. Humán orientáció. A NAV esetében a jogszabályi háttér eleve igyekszik biztosítani a köz szolgálatában állók részére bizonyos előnyöket. Ugyanakkor a Képzési, Egészségügyi és Kulturális Intézet jóvoltából egészségügyi ellátás, színes kulturális és sportprogramok segítik a rekreációt - igaz, zömmel fővárosközpontúan! A szervezet foglalkoztatási szabályzata lehetőséget biztosít a rugalmas, illetve az eltérő munkaidő-beosztás alkalmazására. ${ }^{34}$

4. Belső függés - függetlenség. A nagyon erős belső függés éppen azért lényeges érték, mert az egyes szakágak munkatársainak nagyon gyakran kell együtt, összehangoltan dolgozniuk. Jó példa erre valamennyi olyan akció, ahol a vámosok mélységi ellenőrzés keretében vizsgálnak szállítmányokat, s ezzel egy időben az adóág és a bűnügyi ág munkatársai is információkat kapnak az ellenőrzésekről, így azonnal tudnak - ha kell - nyomozást vagy adóigazgatási eljárást indítani.

5. Erôs vagy gyenge kontroll. A szerepkultúra sajátja az erősen szabályozott jelleg. A hivatásos állomány körében ez még inkább érvényesül, de természetesen a kormánytisztviselők munkája is folyamatosan, több szinten kontrollált.

6. Kockázatvállalás - kockázatkerülés. A kockázatvállalás a hivatásos állománynak - hivatásából adódóan - sajátja, ezek a kompetenciák még hangsúlyosabban érvényesülnek a Bevetési Igazgatóság munkatársai körében, illetve a bünügyi szakterületen. Az adóág e szempontból inkább a skála másik végén található, ott nem elvárás a kockázatok vállalása, már csak azért sem, mert veszélyesebb helyzetekben általában van jelen pénzügyőr is. (Adóági oldalról olykor lehet hallani olyan vélekedést is, hogy a pénzügyőr feladata csupán a biztonság szavatolása.) Itt említhető továbbá, hogy a negyedik pontban említett közös munkavégzést olykor nehezíti, hogy a pénzügyőrök megszokták a „7/24” munkavégzést, míg a volt APEH-esek általában hivatali munkaidőben tudnak gondolkodni.

7. Teljesítményorientáció. A NAV-nál egységes teljesítményértékelési rendszer múködik: minden egyes munkatárs esetében vezetője évente értékeli a teljesítményt, az elvégzett feladatokat. A mindenkori költségvetési törvényben meghatározott - a bevételek teljesüléséhez kötött - jutalmazásból ${ }^{35}$ azok is részesülnek, akik közvetlenül nem szednek be köztartozást (éppenséggel lehet, hogy munkakörükből adódóan csak visszautalnak!), mégis elismerve érezhetik az általuk végzett jogszerü, pontos munkát.

Bérces (é. n.) 44.

A NAV a részére a tárgyévi költségvetési törvényben meghatározott költségvetési támogatáson felül további - személyi juttatásokra, munkaadókat terhelő járulékokra és felhalmozási kiadásokra fordítható - támogatásra jogosult a költségvetési törvényben rögzített bevételi tervek teljesítésével összefüggésben. A bevételi követelményeket, a felhasználható forrás mértékét, jogcímét és ütemezését a költségvetési törvényben kell meghatározni. (NAV tv. 1. § /3/ bek.) 
8. Konfliktustürés - konfliktuskerülés. Ebből a szempontból a NAV erősen bürokratikus szervezetként értékelhető. Az APEH-VP integráció során „a munkatársak szintjén érezhető volt a kiszolgáltatottság, a bizonytalanság, az ismeretlen következményektől való félelem. Nyíltan nem mertek szembeszállni a sorsukról határozó döntéshozókkal, és miközben tehetetlenül figyelték a »fejük felett" zajló eseményeket, sokan passzivitásba vonultak vissza - ez az ellenállás egyik formája". ${ }^{36}$

9. Cél (eredmény) - eszköz (folyamat) orientáció. Bár sokszor elhangzik, és valóban igaz is, hogy a NAV feladatai között kiemelt helyen szerepel az áruk illegális forgalmának megakadályozása, illetve felderítése (hamisított, rossz minőségű, engedély nélkül szállított stb. áruk), az első számú cél mégis a költségvetés bevételeinek biztosítása. Elmondható tehát, hogy a szervezet erőteljesen célorientált, ebben némi hasonlóságot mutat az üzleti szféra profitorientált szervezeteivel. Ugyanakkor a múködéssel szembeni alapvető elvárás a jogszerűség, azaz a folyamatok kontrollálása is fontos.

10. Nyílt rendszer (külső) - zárt rendszer (belső) orientáltság. A NAV folyamatosan figyelemmel kíséri a gazdaság fehér, szürke és fekete szegmensének változásait, és - lehetőségeihez mérten - innovációval vagy a jogalkotó felé tett jelzéssel igyekszik reagálni az új fejleményekre. ${ }^{37}$

11. Rövid vs. hosszú távú időorientáció. A NAV vezetőjének már idézett évértékelője szerint a hivatal stratégiai céljai: 1. szolgáltatások, partnerség, ügyfélközpontú eljárások; 2. adminisztrációcsökkentés, az online megoldások bővítése; 3 . hatékony adóbeszedés; 4. aktív humán tőke, racionalizált múködés. E célok megvalósítása a szervezet szándéka szerint az adótudatosság ösztönzésével, korszerű szolgáltatásokkal és hatékony müködéssel biztosítja a költségvetési bevételeket, és támogatja a gazdasági fejlődést. ${ }^{38}$

\section{A szervezeti kultúra és a szervezeti kommunikáció összefüggései}

Mint láttuk, a Nemzeti Adó- és Vámhivatal - jogállásából eredően - bürokratikus, szerepkultúrára épülő szervezet. Belső formális kommunikációjában értelemszerűen ez tükröződik, hiszen - amint fentebb említettem - egyrészt részletesen szabályozott organizmusról van szó (mind jogszabályi szinten, mind pedig a NAV-rendelkezések szintjén), másrészt pedig a hivatali érintkezésen láthatóak a hivatali stílusjegyek, különösen pedig a jogi szaknyelv mindennapos használata. Tovább árnyalja a képet, hogy a munkatársak egy része hivatásos állományú, a közöttük lebonyolódó kommunikáció ennek megfelelő. A belső formális kommunikáció általánosságban „civil”, azaz

\footnotetext{
Belényesi (2014) 133.

37 Példa erre az elektronikus közútiáruforgalom-ellenőrző rendszer (EKÁER), az online pénztárgépek bevezetése, új technológiák bevezetése a zöldhatár kontrollálásában stb.

38 A NAV vezetőjének évértékelője, 2019. február 7. Forrás: https://nav.gov.hu/nav/sajtoszoba/hirek/Evertekelo20190211.html (2019. 10. 14.)
} 
a Vám- és Pénzügyőrségnél korábban megszokott „meghagyom”, „jelentse” stb. kifejezések nem jelennek meg. Egységes szervezetként csak úgy tud múködni a NAV (is), ha a munkatársak egymás közötti információáramlása magas szintű, vagyis „a rendészeti szervezeteknek is a saját szervezeti kultúrájukat leginkább meghatározó belső kommunikációra kellene a legnagyobb hangsúlyt fektetniük" ${ }^{39}$

A külső kommunikáció jórészt innovatívnak, proaktívnak mondható. A NAV igyekszik ott lenni minden kommunikációs csatornán, akár az írott és elektronikus sajtóról, akár az internetről, a Facebookról vagy a mobilalkalmazásokról beszélünk. A szervezet nyílt rendszer voltát jól szemlélteti dr. Sárközi Alexandra volt bűnügyi szóvivő gondolata a NAV Facebook-oldalának elindításáról: „a »Facebook-lét « többek között segíthet levetkőzni a "mumus hivatal « képét". ${ }^{40}$ Az egységes arculat kialakítását segítette a többi között az, hogy a korábbi három helyett ma már egyetlen szóvivő jelenik meg a NAV arcaként és hangjaként. Igaz, ő jórészt adószakmai kérdésekben szólal meg, míg a rendészeti, bűnügyi (azaz inkább a pénzügyőri területeket érintő) témák általában írott formában, a honlapon vagy a Facebookon láthatóak. „2015-ben már közel 18 millió alkalommal kattintottak a NAV oldalára és egyre ismertebb a 2013-ban indított Facebook-profil is." 41

\section{Összefoglalás}

A Nemzeti Adó- és Vámhivatal kilenc évvel ezelőtt egy „civil” közigazgatási szerv és egy katonai hierarchián, alá-fölé rendeltségi viszonyokon alapuló rendvédelmi szerv öszszevonásával jött létre. Az integráció lebonyolításának tanulsága, hogy „a felső vezetőre a hosszabb távú, koncepcionális megközelítés volt jellemző a kérdésben, ami egy gyakorlatias megközelítéssel párosult, a középvezetők pedig a gyakorlatiasság mellett egyben feladat- vagy kapcsolatorientált módon problémaérzékenyek is voltak. Kiderült, hogy a vezetőket kevésbé viselte meg a változás ezen szegmense, annál inkább a munkatársakat: kiszolgáltatottnak érezték magukat, inkább elszenvedői voltak a megváltozott értékeknek, szokásoknak, semmilyen befolyást nem tudtak gyakorolni ezekre". ${ }^{42}$ Mára a szervezet - bár nem titkoltan állandóan változó, képlékeny állapotban van - többnyire képes mind belső, mind külső kapcsolataiban egységes értékeket felmutató hivatalként megjelenni.

\footnotetext{
Molnár (2016) 51-54.

40 Láng-Miticzky (2013) 20.

41 Ambrus-Széles (2017) 462-475.

2 Belényesi (2014) 135.
} 


\section{IRODALOMJEGYZÉK}

Ambrus Rita Anna - Széles Zsuzsanna (2017): Az elektronikus adóügyintézés fejlesztése és gyakorlata. Pénzügyi Szemle, 62. évf. 4. sz. 462-475. Forrás: www.penzugyiszemle.hu/documents/ambrusszeles-2017-4-mpdf_20180110164202_25.pdf (2019. 10. 18.)

Bakacsi Gyula (1996): Szervezeti magatartás és vezetés. Budapest, Közgazdasági és Jogi Könyvkiadó.

Belényesi Emese (2014): Változásmenedzsment a közigazgatásban. Budapest, Nemzeti Közszolgálati Egyetem. Forrás: https://opac.uni-nke.hu/webview?infile=\&sobj=9698\&source=webvd\&cgimime=application\%2Fpdf\%0D\%0A (2019. 10. 14.)

Bérces Kamilla (é. n.): A Nemzeti Adó-és Vámhivatal munkajogi-humánpolitikai vizsgálata a 2011-2013 közötti idöszakban. Budapest, Magyar Közlöny Lap- és Könyvkiadó. Forrás: http://oszkdk.oszk. hu/storage/00/01/24/07/dd/1/AROP-2-2-17_HU_14.pdf (2019.10. 07.)

Czuprák Ottó - Kovács Gábor (2013): Vezetés- és szervezéselmélet. Budapest, Nemzeti Közszolgálati Egyetem.

Dettné Légrády Ilona (2000): A magyar vámtörténet röviden. Rendvédelmi Füzetek, 40. sz. 3-12.

Jávor István - Rozgonyi Tamás (2007): A szervezetek és a munka világa. H. n., Zsigmond Király Főiskola - L'Harmattan Kiadó.

Klein Balázs - Klein Sándor (2006): A szervezet lelke. Budapest, Edge 2000 Kiadó.

Kovácsics Iván et al. szerk. (é. n.): Emlékkönyv a Vám-és Pénzügyörség történetérôl 1867-2000. Budapest, VIVA Média Holding.

Láng-Miticzky András (2013): Három, kettő, egy, LÁJK! Pénzügyőr, 2013. október. 20.

Molnár Katalin (2016): A kommunikáció szerepe a rendészeti munkában. A kommunikációs készségek fejlesztési lehetőségei a rendészeti képzésben. Határrendészeti Tanulmányok, 13. évf. 1. sz. 51-54. Forrás: https://rtk.uni-nke.hu/document/rtk-uni-nke-hu/2016-1.\%20szám.pdf (2019. 10. 18.)

Szabó Andrea (é. n.): A Nemzeti Adó- és Vámhivatal jogelődjeinek összevetése. In: Az adó- és vámigazgatás szervezete és müködése. [Kutatásvezető: Szabó Andrea.] Kézirat. (Készült a Nemzeti Közszolgálati Egyetemen a Wekerle Sándor Alapkezelő megbízásából.) 36-39.

\section{Jogforrások}

2004. évi XIX. törvény a Vám- és Pénzügyőrségről (VP tv.). Magyar Közlöny, 50. sz. 4434-4444.

2010. évi CXXII. törvény a Nemzeti Adó- és Vámhivatalról (NAV tv.). Magyar Közlöny, 177. sz. 2522825285.

273/2006. (XII. 23.) Korm. rendelet az Adó- és Pénzügyi Ellenőrzési Hivatalról. Magyar Közlöny, 161. sz. 13072-13077.

26/2015. (XII. 30.) NGM utasítás a Nemzeti Adó- és Vámhivatal Szervezeti és Múködési Szabályzatáról (NAV SZMSZ). Hivatalos Értesitőo, 66. sz. 7727-7777.

A NAV vezetőjének évértékelője, 2019. február 7. Forrás: https://nav.gov.hu/nav/sajtoszoba/hirek/ Evertekelo20190211.html (2019. 10. 14.) 


\section{ABSTRACT}

\section{Organisational Culture of the Tax and Customs Authority}

\section{SUBA László}

The author of the study outlines the history of the establishment of the National Tax and Customs Administration and then analyses the organisational culture of the office based on an outline of the hierarchy of the National Tax and Customs Administration. In addition, it attempts to provide insight into the specifics of the integration of the two legal predecessors, and finally addresses some of the communication issues of the organisation. The author aims, on the one hand, to give insight into the functioning of a very specific organisation that performs "law enforcement tasks" and, on the other hand, to briefly document the history of the merger of "civilian" and armed law enforcement agencies.

Keywords: communication, customs, National Tax and Customs Administration, organisational culture, tax administration 